\title{
Deposit Money Banks' Credit and Agricultural Output in Nigeria
}

\author{
Chioma Chidinma George-Anokwuru ${ }^{1}$ \\ ${ }^{1}$ Department of Economics, Faculty of Social Sciences, University of Port Harcourt, Nigeria \\ Correspondence: Chioma Chidinma George-Anokwuru, Department of Economics, Faculty of Social Sciences, \\ University of Port Harcourt, East West Road, Choba, P. M. B 5323, Port Harcourt, Rivers State, Nigeria. E-mail: \\ chiomanwoga@yahoo.com
}

Received: April 26, 2018; Accepted: May 30, 2018; Published: June 30, 2018

\begin{abstract}
Absract
Agriculture was the mainstay of the Nigerian economy before the period of oil boom. But after the oil boom, growth and development in agriculture has been constrained by high interest rate by deposit money banks as well as in ability to access credit or loan by farmers. This scenario led to increase in unemployment, poverty and food shortage. Given these problems, the paper examined deposit money banks' credit and agricultural sector output in Nigeria from 1985-2015. To this effect, secondary data on agricultural sector output, deposit money bank's credit to agricultural sector, interest rate and money supply was collected from Central Bank of Nigeria Statistical Bulletin. The data collected was analyzed by the econometrics techniques of Augmented Dickey Fuller unit root test, co-integration test and parsimonious Error Correction Model. The unit root and co-integration tests show that all the variables were stationary and co-integrated. The parsimonious Error Correction Model results show that the regression coefficient of deposit money bank's credit to agricultural sector in explaining its contribution to agricultural output is positive and statistically significant at 5 percent level. The regression coefficient of interest rate appeared with negative sign but statistically not significant. Also, the coefficient of money supply is positive and significantly related with agricultural output. Based on these findings, the paper recommends amongst others that; there should be continuity and consistency of macroeconomic policy measures in the agricultural sector especially in the area of sectorial allocation of credit as well as single digit interest rate target. Also, government should domesticate Food and Agriculture O's recommendation of 25 percent of capital allocation to agricultural development in order to increase the agricultural production and hence economic growth and development.
\end{abstract}

Keywords: Agriculture Output, Banks' Credit, Money Supply, Interest Rate, Food Shortage, FAO

\section{Introduction}

The function of banks as financial intermediation involves channeling funds from surplus unit to the deficit unit of the economy. According to Adamu (2006), the provision of credit with sufficient consideration for the sectors volume and price system is a way to generate self-employment opportunities. This is because credit helps to create and maintain a reasonable business size as it is used to establish and expand the business taking advantage the economy of scale. It can also be used to improve informal activity and increase its efficiency. The role of agriculture in transforming both the social and economic frame work of an economy cannot be over emphasized. Anyanwu (1993) posits that "agriculture has been the main source of gainful employment from which Nigeria nation can feed its population, providing the nation's industries with local raw materials and as a reliable source of government revenue. Adekanya (1986) stated that in making credit available, banks are rendering a great social service because through their activities, production is increased, capital investment are expanded and a higher standard of living is realized. The Nigerian economy, until today is still dependent on primary products both as foreign exchange earner and contributor to gross domestic product.

Nigeria is endowed with vast farmland and conducive geographical condition. Despite this great potential, there is not much to show for it (Salami and Arawomo, 2013). Poor credit has been identified by several authors as one of the factors responsible for the poor performance of agricultural sector in Nigeria. According to Obilor (2013), commercial banks have no kin interest in agricultural finance. To encourage the banks, the government established the Agricultural Credit Guarantee Scheme (ACGS) to provide guarantees against inherent risk in agricultural lending. This measure could not achieve the intended objectives because agricultural being both labour and capital intensive venture requires huge capital outlay (Nwankwo,2013). The effort of the government to tackle this menace have not yielded the desired result (Udensi, Orebiyi, Ohajianya and Eze, 2012). 
Nigeria is endowed with huge expanse of fertile arable land, and graze land, as well as a large active population that can sustain a high productive and profitable agricultural sector. Adubi (2000) admits that this enormous resource base if well managed could support a vibrant agricultural sector capable of ensuring self sufficiency in food and raw materials for the industrial sector as well as, providing gainful employment for the teeming population and generating foreign exchange through exports. In spite of these endowments, the sector has continued to record a declining productivity. The capacity of the sector to fulfill its traditional role in the Nigerian economy has been constrained by various social-economic and structural problems. These include unavailability of credits to local farmers, discovery of oil, high interest rates on loans to farmers, rural- urban migration and ineffective institutions charged with policy implementations.

The aim of this research is to evaluate the effect of bank credit on agricultural sector in Nigeria from 1985 to 2015 .

The specific objectives are to:

i. to determine the effect of bank sector credit on agricultural output in Nigeria within the period of this study.

ii. to evaluate the impact of interest rate on agricultural output in Nigeria within the same period of study

\section{Literature Review}

\subsection{The Quantity Theory of Credit}

Werner (1992) in his work towards a quantity theory of disaggregated credit and international capital flows presented the Quantity Theory of Credit with a central focus on different equation of exchange distinguishing between money used for GDP-transactions and money used for non GDP-transaction. He further stressed that money should not be defined as bank deposits or other aggregates of private sector savings. More so, that bank should not be seen as not being financial intermediaries that lend existing money, rather creators of new money through the process of lending. In addition, growth of GDP requires increased transaction in economic activities, which in turn require larger amount of money to be used for such transactions; therefore, the money used for transactions can only rise if banks create more credits. The effect of bank credit depends on its quantity and quality which is defined as whether it is used for unproductive transactions (credit for consumption or asset transactions, producing unsustainable consumer or asset inflation, respectively) or productive transactions (delivering noninflationary growth). Credit used for productive transactions aims at income growth and is sustainable; credit for asset transactions aims at capital gains and is unsustainable. Werner has argued that the banking sector needs to be reflected appropriately in macroeconomic models since it is the main creator and allocator of the money supply, through the process of credit creation by individual banks.

\subsection{The Balance Sheet Credit Channel Theory}

The balance sheet channel theorizes that the size of the external finance premium should be inversely related to the borrower's net worth. The greater the net worth of the borrower, the more likely she may be to use self-financing as a means to fund investment. Higher net worth agents may have more collateral to put up against the funds they need to borrow, and thus are closer to being fully collateralized than low net worth agents. As a result, lenders assume less risk when lending to high-net-worth agents, and agency costs are lower. The cost of raising external funds should therefore be lower for high-net-worth agents. Since the quality of borrowers' financial positions affect the terms of their credit, changes in financial positions should result in changes to their investment and spending decisions. This balance sheet channel arose due to shifts from central bank's policy not only affects market interest rate but also the financial positions of borrowers.

\subsection{The Bank Lending Credit Channel Theory}

The bank lending channel theorizes that changes in monetary policy will shift the supply of intermediated credit, especially credit extended through commercial banks. Monetary policy actions may affect the supply of loanable funds available to banks (i.e. a bank's liabilities), and consequently the total amount of loans they can make (i.e. a bank's assets). Banks serve to overcome informational problems in credit markets by acting as a screening agent for determining credit-worthiness. Thus many agents are dependent on banks to access credit markets. If the supply of loanable funds banks possess is affected by monetary policy changes, then so too should be the borrowers who are dependent on banks' funds for business operations. Firms reliant on bank credit may either be shut off from credit temporarily or incur additional search costs to find a different avenue through which to obtain credit. This will increase the external finance premium, consequently reducing real economic activity. The bank lending channel presumes that monetary policy changes will drain bank deposits so long as banks cannot easily replace the short-fall in deposits by issuing other uninsured liabilities. 


\subsection{Empirical Review}

Nnamocha and Eke (2015) examined the effect of bank credit and agricultural production in Nigeria between 1970 and 2013. Adopting an Error Correction Model (ECM), the result of their empirical findings indicated that there is a long-run relationship between bank credit and agricultural production. The result also showed that only industrial output influenced agricultural production in the short run.

Ogbanye, Yahaya and Kolawole (2012) examined the effect of commercial banks loan on agricultural sector in Nigeria from 1981 to 2007. The Ordinary Least Square method was used and findings revealed that commercial banks loan has contributed positively and significantly to agricultural development in Nigeria.

Anyanwu (2009) applied Ordinary Least Square technique and studied the determinants of aggregate agricultural productivity among smallholder farmers in Rivers State. Results showed that farm land, labour input, planting materials, age of farmers, farming experience and level of education are the main significant determinants of aggregate agricultural productivity in the state.

Enyim, Ewno and Okoro (2013) examined banking sector credit and performance of the Agricultural sector in Nigeria. The study applied cointegration technique and the results showed that total money stated as Government Expenditure on agriculture is not statistically significant, however the result revealed that commercial banks' credit to the agricultural sector has a positive relationship with agricultural productivity.

Nwankwo (2013), examined agricultural financing in Nigeria and its implication on the growth of Nigerian economy using ordinary least square method. The study revealed that there is significant relationship between agricultural financing and the growth of the Nigerian economy and the level of loan repayment rate over the years has negatively impacted significantly on the growth of Nigerian economy.

Kareem, Bakare, Raheem, Olagumela, Alawode and Ademoyewa (2013), examined the factors influencing Agricultural output in Nigeria and the causality between Agricultural outputs and macro-economic variables. The study adopted regression analysis and the result revealed that foreign direct investment, commercial bank loan, interest rate and food import value have positive relationship with Agricultural output.

Udih (2014), investigated banks credit and agricultural development in Nigeria. The data was analysed using percentage , mean, Standard Deviation and Pearson product moment correlation to test the hypothesis. The study found out that banks' credit and advances to agricultural entrepreneurs promote agricultural development and productivity and regulated banks' credit to the entrepreneurs has little or no impact on the entrepreneurship performance

\section{Methodology}

The study applied secondary data from the period of 1985-2015 collected from CBN statistical bulletin and applied a three stage methodical process to examine the relationship between deposit money banks credit and agricultural output in Nigeria. One was to check for the order of integration of the variables using Augmented Dickey Fuller Unit Root test proposed by Dickey and Fuller (1979), the second was to check for the possibility of a long run relationship using Johansen co-integration test proposed by Johansen (1988); the third was to adjust the short run error to long run equilibrium relationship amongst the variables.

The model for the study is stated in a log-linear form in order to put the variables on the same scale and also reduce the problem of multicollinearity.

$$
\text { Thus; } \operatorname{LnAGQ}=\mathrm{Ln}_{0}+\alpha_{1} \operatorname{LnDBC}_{\mathrm{t}}+\alpha_{2} \operatorname{LogMSP}_{\mathrm{t}}+\alpha_{3} \operatorname{LnITR}_{\mathrm{t}}+\mathrm{U}_{\mathrm{t}}
$$

Where; $\mathrm{AGQ}=$ Agricultural Production Output, $\mathrm{DBC}=$ Deposit Money Bank Credit to Agriculture, MSP=Broad Money Supply, ITR $=$ Interest Rate, $\mathrm{Ln}=$ Natural Logarithm, $\mathrm{U}=$ Error Term, $\mathrm{t}=$ Time/Period, $\alpha=$ Intercept parameter, $\alpha 1-\alpha 3=$ Slope Parameters

On the apriori, we expect $\alpha_{1}>0, \alpha_{2}>0$ and $\alpha_{3}<0$

The unit root test via the ADF test which precedes the cointegration and ECM tests in order to test for stationarity of the variables. The unit root model is presented thus:

for levels

$$
\Delta Y_{l}=\alpha Y_{t-1}+\sum_{\mathrm{i}=1}^{\mathrm{m}} \beta \Delta Y_{t-1}+\delta+Y_{l}+\varepsilon_{l}
$$

$$
\Delta \Delta Y_{l}=\alpha \Delta Y_{t-l}+\sum_{\mathrm{i}=1}^{\mathrm{m}} \beta \Delta \Delta Y_{t-l}+\delta+Y_{l}+\varepsilon_{l}
$$

for first difference $\Delta \mathrm{Y}$ is the first difference of the series, $\mathrm{m}$ is the number of lags and $\mathrm{t}$ is the time. 
Meanwhile, assuming the integration of order I(1) and cointegration between the agricultural sector output, Deposit Money Banks Credit to Agricultural sector (DBC) Money Supply (MSP) and Interest Rate (ITR). Thus, Johansen (1988) general form of co-integration is given by

$$
\mathrm{Y}_{\mathrm{t}}=\mu+\Delta_{1} \mathrm{Y}_{\mathrm{t}-1}+\cdots+\Delta \mathrm{q} \mathrm{Y}_{\mathrm{t}-\mathrm{P}}+\mathrm{U}_{\mathrm{t}}
$$

Where: $\Delta$ is the changes in the different operator, $Y_{t}$ is the vector of variables that are integrated, $t-1$ is the lag length, $t-p$ is the number of co-integrating equation and $U_{t}$ is the error term.

Given the existence of co-integration in equation 3.4, the following ECM was formulated:

$$
\Delta \mathrm{AGQ}_{\mathrm{t}}=\ln \beta_{0}+\Sigma \beta_{1} \Delta \mathrm{DBC}_{\mathrm{t}}+\Sigma \beta_{2} \Delta M S P_{\mathrm{t}}+\Sigma \beta_{3} \Delta I T R_{\mathrm{t}}+\mathrm{ECM}_{\mathrm{t}-1}
$$

From equation 3.5, $\Delta$ indicates difference operator, $\mathrm{t}$ implies time, $\beta_{0}$ is the intercept and $\mathrm{ECM}_{\mathrm{t}-1}$ is the error correction mechanism obtained from the long-run co-integration regression. While $\beta_{1-} \beta_{3}$ are the coefficients of explanatory variables.

\section{Results and Discussion}

\begin{tabular}{|c|c|c|c|c|c|c|c|c|c|}
\hline \multirow[b]{2}{*}{ Variable } & \multirow{2}{*}{$\begin{array}{l}\text { ADF } \\
\text { Test @ } \\
\text { Level }\end{array}$} & \multicolumn{2}{|c|}{ Critical Value } & \multirow[b]{2}{*}{$10 \%$} & \multirow{2}{*}{$\begin{array}{l}\text { ADF } \\
\text { Test @ } \\
1^{\text {ST }} \text { Diff }\end{array}$} & \multicolumn{3}{|c|}{ Critical Value } & \multirow{2}{*}{$\begin{array}{l}\text { Order of } \\
\text { Integration }\end{array}$} \\
\hline & & $1 \%$ & $5 \%$ & & & $1 \%$ & $5 \%$ & $10 \%$ & \\
\hline AGQ & -2.9597 & $\begin{array}{l}- \\
3.6702\end{array}$ & $\begin{array}{l} \\
2.9640\end{array}$ & $\begin{array}{l}- \\
2.6210\end{array}$ & -6.0241 & $\begin{array}{l} \\
3.6892\end{array}$ & $\begin{array}{l} \\
2.9719\end{array}$ & $-\overline{2.2651}$ & $1(1)$ \\
\hline DBC & -2.2411 & $\begin{array}{l}- \\
3.6702\end{array}$ & $\begin{array}{l}- \\
2.9640\end{array}$ & $\begin{array}{l}- \\
2.6210\end{array}$ & -4.7021 & $\begin{array}{l}- \\
3.6793\end{array}$ & $\begin{array}{l}- \\
2.9678\end{array}$ & $\begin{array}{l}- \\
2.6230\end{array}$ & 1(1) \\
\hline MSP & -1.7201 & $\begin{array}{l}- \\
3.6892\end{array}$ & $\begin{array}{l}- \\
2.9719\end{array}$ & $-\overline{2.6251}$ & -7.0343 & $\begin{array}{l}- \\
3.6892\end{array}$ & $\begin{array}{l}- \\
2.9719\end{array}$ & - & $1(1)$ \\
\hline ITR & -5.4069 & $\begin{array}{l}- \\
3.6702\end{array}$ & $\begin{array}{l}- \\
2.9640\end{array}$ & $\begin{array}{l}- \\
2.6210\end{array}$ & - & - & - & - & $1(0)$ \\
\hline
\end{tabular}

Table 4.1 Unit Root Test for Stationarity (Augmented Dickey Fuller)

The Augmented Dickey Fuller (ADF) test was used to investigate stationarity of the variables.

Source: Authors' Computed Result Using (E-Views 9.0)

The ADF unit root test of stationarity test result presented in table 4.1 shows that the all the variables used for the analysis were stationary at $1 \%, 5 \%$ and $10 \%$ levels. Although all the variables were not stationary at level except interest rate (ITR). In line with Granger and Newbold (1974), the non-stationary variables were differenced once and they were stationary. Therefore agricultural output (AGQ), deposit money banks credit to agricultural sector (DBC) and broad money supply (MSP) were stationary at order one. The variables were said to be stationary because each of their respective ADF values at either level or first difference were found to be greater than their critical values at $1 \%, 5 \%$ and $10 \%$. Thus, the null hypothesis of no unit root was rejected.

Table 4.2 Johansen Co-integration Test Result

\begin{tabular}{lllll}
\hline $\begin{array}{l}\text { Eigen value } \\
\text { K=3, r-2 }\end{array}$ & Trace Statistics & $\mathbf{5 \%}$ critical value & Prob. ${ }^{* *}$ & Hypothesis of CE(s) \\
\hline 0.772896 & 83.00372 & 47.85613 & 0.0000 & None * \\
0.688609 & 42.98034 & 29.79707 & 0.0009 & At most 1 * \\
0.346263 & 11.47923 & 15.49471 & 0.1837 & At most 2 \\
0.000107 & 0.002876 & 3.841466 & 0.9558 & At most 3 \\
\hline
\end{tabular}

Note: $\mathrm{r}=$ number of cointegrating vectors and $\mathrm{k}=$ number of lags in model. $*$ rejection of the $\mathrm{H} 0$

Source: Author's Computed Result Using (E-Views 9.0)

The Johansen co-integration trace statistics test results as reported in table 4.2 showed that there are two cointegrating equations at $5 \%$ level of significance at lag three. This is because two of the Trace Statistic values were 
found to be greater than the critical values at $5 \%$. This is strong evidence from the unit root test conducted, where almost all the variables were stationary at first difference. Therefore, there exists a long-run relationship or equilibrium among the variables. Thus, the null hypothesis of no co-integration was rejected.

Table 4.3 Error Correction Mechanism Result for the Estimated Model

\begin{tabular}{llll}
\hline Variables & Coefficient & T-Statistics & Probability \\
\hline C & 0.045019 & 3.143008 & 0.0063 \\
DLOG(AGQ(-1)) & 0.432804 & 2.467689 & 0.0253 \\
DLOG(AGQ(-2)) & -0.337411 & -1.320441 & 0.2053 \\
DLOG(AGQ(-3)) & 0.383003 & 1.881421 & 0.0782 \\
DLOG(DBC(-1)) & 0.016103 & 4.134209 & 0.0005 \\
DLOG(MSP(-1)) & 0.178398 & 2.764005 & 0.0138 \\
D(ITR(-1)) & -0.000138 & -0.755596 & 0.4609 \\
ECM(-1) & -0.000823 & -2.802491 & 0.0128 \\
$\mathrm{R}^{2}=0.6686$ & DW-Stat $=1.9447$ & F-Stat. $=3.2283$ & F-Prob $=0.0180$ \\
\hline
\end{tabular}

Source: Author's Computed Result Using (E- view 9.0)

A cursory look at the parsimonious Error Correction Model (ECM) in table 4.3 indicated that the dynamic model is a good fit. This is so because the variation in the dependent variable accounted for 67 percent of the total variation in the explanatory variables in the model. Specifically, the $\mathrm{R}^{2}$ value of 0.6688 indicated that the variation in agricultural sector output (AGQ) explained by (deposit money banks credit, broad money supply and interest rate) is 67 percent. Therefore, the explanatory power of the model estimated is 67 percent. Also, the model good fit is further buttressed by high value of f-statistic of 3.2283 which is statistically significant at the $5 \%$. The Durbin Watson (DW) value of 1.9447, which is approximately 2.0, suggests a lesser degree of autocorrelation. Thus, the model is good for policy formulation and implementation.

Meanwhile, the coefficient of the parameter of error correction mechanism is (-0.000823) and statistically significant at 5 percent level. This shows that about 0.823 percent disequilibria in the agricultural sector output in the previous year were corrected for in the current year. It therefore, follows that the ECM could rightly correct any deviations from short run to long-run equilibrium relationship between the dependent and the explanatory variables.

Furthermore, the coefficient of deposit money banks' credit to agriculture (DBC) is positively signed and statistically significant at 5 percent level. The implication of this result is that a percentage increase in deposit money banks' credit to agriculture contributed positively to 0.016103 percent increase the output of the agricultural sector in Nigeria during the period of study. Also, given the significant impact of deposit money banks' credit to agriculture on the output of the agricultural sector, the alternative hypothesis was accepted. Similarly, the coefficient of broad money supply (MSP) is positively signed and statistically significant at 5 percent level. The implication of this result is that a percentage increase in money supply contributed positively to 0.178398 percent increase the output of the agricultural sector in Nigeria during the period of study. Also, given the significant impact of money supply on the output of the agricultural sector, the alternative hypothesis was accepted.

Meanwhile, the coefficient of interest rate (ITR) is negatively signed but statistically not significant at 5 percent level. The implication of this result is that a percentage increase in interest rate will reduce the output of the agricultural sector in Nigeria by $0.000138 \%$ during the period of study. Also, given that the t-statistic of interest rate is not significant with the output of the agricultural sector, the null hypothesis was accepted.

\section{Conclusion}

The study confirms the fact that one of the most important functions of banks and other financial institutions is to make credit available to the investors especially to the agricultural sector. This is because low credit or high interest rate will amount to low level of investment which transmits to low agricultural output. The agriculture sector output and its development depend to a significant extent on the credit and financing it receives from the banking system. The agriculture sector cannot be well developed and capable of meeting the needs and requirements of the household and industrial sectors if the structure of agriculture financing is not adequate. 


\section{Recommendations}

1. The government through its relevant authorities should design a favourable policy that will enable banks to make credit more available to farmers.

2. The government should formulate policies that will encourage the banks to give loans to farmers at a concessionary interest rate.

3. Government should make deliberate efforts to expand its agricultural expenditure by increasing its financial grants to agricultural firms and small scale farmers.

\section{References}

Adekanye, F. (1986). Elements of Banking in Nigeria F \& A Publishers Ltd in Association with Graham Burn $3^{\text {rd }}$ Edition, Lagos: 162-169.

Adubi, A. A. (2000). The effect of exchange rate policy on Cameroon's Agricultural Competitiveness. $4^{\text {th }}$ Edition. ARC Publishers, Nairaobi; 2000. Banker, Vol. III, 105-109.

Anyanwu, J. C. (1993). Monetary Economics Theory Policy and Institution. Hybrid Publishers Ltd, Onitsha Nigeria.

Anyanwu, M. O. (1997). Non oil export-led growth ineconomic development. 2nd Edition. Longman Nigeria Plc, Lagos; 1997.

Dickey, D. A., \& Fuller, W. A. (1979). Distribution of the Estimators for Autoregressive Time Series with a Unit Root. Journal of the American Statistical Association, 74(1), 427-431. https://doi.org/10.2307/2286348

Enyim, O. B., Ewno, E. N., \& Okoro, O. T. (2013). Banking sector credit and the performance of the agricultural sector in Nigeria. European Journal of Scientific Research, 23(2), 35-55.

Granger, C. W. J., \& Newbold, P. (1974). Spurious Regression in Econometrics. Journal of Econometrics, 2, 111120. https://doi.org/10.1016/0304-4076(74)90034-7

Johansen, S. (1988). Statistical A n a 1 y s is of Cointegrating Vectors. Journal of Economic Dynamics and Control, 12, 231- 254. https://doi.org/10.1016/0165-1889(88)90041-3

Kareem, K. R. O., Bakare, H. A., Raheem, K. A., Olagumela, S. E., Alawode, O. O., \& Ademoyewa, G. R. (2013). Analysis of factors influencing agricultural output in Nigeria: macroeconomic perspectives. American Journal of Business, Economics and Management, 1(1), 9-15.

Nnamocha, P. N., \& Eke, C. (2015). Bank Credit and Agricultural Output in Nigeria; An Error Correction Model (ECM) Approach. British Journal of Economics, Management \& Trade, 10(2), 1-12. https://doi.org/10.9734/BJEMT/2015/19884

Nwankwo, O. (2013). Agricultural financing in Nigeria: An empirical study of Nigerian agricultural co-operative and rural development bank (NACRDB): 1990-2010. Journal of Management Research, 5(2), 28-44. https://doi.org/10.5296/jmr.v5i2.2806

Obilor, S. I. (2013). The impact of commercial banks' credit to agriculture on agricultural development in Nigeria: An econometric analysis. International Journal of Business Humanities and Technology, 3(1), 85-95.

Ogbanje, E. C., Yahaya, M. A., \& Kolawole, F. (2012). Effect of commercial banks' loan on agricultural gross domestic product (GDP) in Nigeria from 1981 to 2007. Retrieved March 18, 2015, from http://www.patnsukjournal.net/currentissue

Salami, A., \& Arawomo, D. F. (2013). Empirical analysis of agricultural credit in Africa: Any role for institutional factors? Tunis, Tunisia, Africa Development's Work Paper, Series 192.

Udensi, A. I., Orebiyi, J. S., Ohajianya, D. O., \& Eze, C. C. (2012). Determinants of macroeconomic variables that affect agricultural production in Nigeria. International Journal of Agric and Rural Development, 15(3), 11691173.

Udih, M. (2014). Bank credits and agricultural development: Does it promote entrepreneurship performance? International Journal of Business and Social Science, 5(11), 102-107.

Werner, R. A. (1992). Towards a quantity theory of disaggregated credit and international capital flows', Paper presented at the Royal Economic Society Annual Conference, York, April 1993 and at the 5th Annual PACAP Conference on Pacific-Asian Capital Markets in Kuala Lumpur, June 1993. 


\section{Copyrights}

Copyright for this article is retained by the author(s), with first publication rights granted to the journal.

This is an open-access article distributed under the terms and conditions of the Creative Commons Attribution license (http://creativecommons.org/licenses/by/4.0/). 